\title{
QTL Mapping of Panicle Architecture and Yield- related Traits Between Two U.S. Rice Cultivars 'LaGrue' and 'Lemont'
}

\section{Adam Rice}

University of Arkansas Fayetteville

\section{Dustin North}

University of Arkansas Division of Agriculture

Karen Ann-Kuenzel Moldenhauer

University of Arkansas Division of Agriculture

Andy Pereira

University of Arkansas Division of Agriculture

Ainong Shi

University of Arkansas Fayetteville

Ehsan Shakiba ( $\nabla$ eshakiba@uark.edu )

University of Arkansas Division of Agriculture https://orcid.org/0000-0001-7264-6351

\section{Research Article}

Keywords: Grain yield, QTL, Rice Research and Extension Center, rice breeding

Posted Date: March 30th, 2021

DOI: https://doi.org/10.21203/rs.3.rs-299812/v1

License: (1) This work is licensed under a Creative Commons Attribution 4.0 International License.

Read Full License 
1 QTL Mapping of Panicle Architecture and Yield-Related Traits Between Two U.S. Rice Cultivars 'LaGrue'

and 'Lemont'

3 Adam Rice ${ }^{1}$, Dustin North ${ }^{1}$, Karen Ann-Kuenzel Moldenhauer ${ }^{1}$, Andy Pereira ${ }^{2}$, Ainong Shi $^{3}$, Ehsan Shakiba ${ }^{1}$

4 Corresponding Author: Ehsan Shakiba eshakiba@uark.edu

5

$6 \quad{ }^{1}$ Rice Research and Extension Center, 2900 AR-130, Stuttgart, AR, US

$7 \quad{ }^{2}$ Dep. of Crop, Soil and Environmental Sciences, University of Arkansas, Fayetteville, AR, US

$8{ }^{3}$ Dep. of Horticulture, University of Arkansas, Fayetteville, AR, US

9 Abbreviations:

10 HD, 50\% Heading Date; FLL, Flag Leaf Length; FLW, Flag Leaf Width; PBN, Primary Branch Number; PH,

11 PlantHeight; PL, Panicle Length; SBN, Secondary Branch Number.

13 This work was supported in part by funding provided by the rice farmers of Arkansas and administered by the

15

16

17

18 


\section{ABSTRACT}

24 Grain yield is a quantitative trait that is determined by several agronomic traits. Unfortunately, there is little

25 information about the genetics behind yield components in U.S. rice cultivars. The objective of the study were to 1) conduct a QTL study for identification of chromosome regions associated with yield traits in two US developed rice cultivars and 2) identify candidate genes in major QTL regions related to yield traits. Four rice cultivars were evaluated in the summer 2017 at the University of Arkansas System Division of Agriculture's Rice Research and Extension Center (RREC) at Stuttgart, AR for 15 agronomic traits associated with yield. Of the four cultivars, "LaGrue" had a higher number of seeds/panicle, number of primary panicle branches/panicle, and number of seeds/plant and "Lemont", despite having longer panicles and higher 100 seed weight/panicle, produced the least number of seeds among the cultivars. A bi-parental population was developed from a cross between LaGrue and Lemont for QTL analysis. Leaf samples from $\mathrm{F}_{2}$ plants were collected for genetic analysis. A set of $322 \mathrm{~F}_{2: 3}$ lines were evaluated in a randomized complete block design (RCBD) for several agronomic traits at two locations with three replications for each line. A total of 17 major QTLs were detected including two major QTLs for plant height on chromosome 1 and two major QTLs for flag leaf length and panicle length on chromosome 8 with seven candidate genes found in these regions. The results from the study would be useful for marker assisted selection in rice breeding.

\section{INTRODUCTION}

Rice is one of the most important food crops in the world along with wheat and maize (IRRI 2019). About 140 million hectares of rice are harvested in the world annually. Approximately half of the world's population relies on rice as part of its diet (Ricepedia 2019). Human consumption of rice accounts for $85 \%$ of global production (IRRI, 2019). In the U.S., Arkansas is the top rice producing state accounting for about $48 \%$ of total U.S. rice production (Hardke 2018). Rice is one of the top three cash crops for Arkansas farmers, and in 2019 rice producers harvested about 1.126 million acres of rice (Hardke 2019).

Selecting for higher grain yield is one of the main objectives for public and private breeding programs in the U.S. and around the world. Grain yield is a complex quantitative trait consisting of multiple yield components (Xing et al. 2010). Yield components such as number of tillers/plant, number of panicles/plant, number of 
seeds/panicle, and seed weight/panicle have been found to contribute to overall yield in rice cultivars (Devi et al. 2017; Samonte et al. 1998). Each yield component can be controlled by multiple genes that have a small effect on the phenotype and are greatly affected by the environment (Xing et al. 2010). Many QTL (quantitative trait locus) mapping studies have been done over the years searching for major QTL for use in breeding. Sun et al. (2017) found twelve QTLs for grain number, panicle length, number of primary panicle branches, and number of secondary branches on chr. 6 in four backcross populations between an indica hybrid restorer line 'HR1128' assigned as the donor parent and the japonica cultivar 'Nipponbare' the recurrent parent. Zhang et al. (2015) found two QTLs for panicle length on chr's 6 and 8 in four backcross populations resulting from the cross Nipponbare, the recurrent parent, and indica line 'WS3', the donor parent. They found that the QTL on chr.6 had a larger effect with longer panicles and increased number of primary and secondary branches than the QTL on chr. 8. Han et al. (2017) found five major QTLs for heading date and plant height under different day-length conditions using a RIL population derived from the indica line 'Zenshan 97' and japonica line 'Xizang 2'. Two major QTLs for heading date on chromosomes 7 and one on chromosome 8 were detected under long day conditions in all 3 years of the study along with major QTLs for plant height on chromosome 1 and 7 that were detected in all 3 years. Zhu et al. (2011) detected a QTL for panicle number on chr.1 using an introgression line "C3074" derived from a set of 112 CSSL lines that were developed from Nipponbare, as the donor parent, and indica line 'Guangluai 4" as the recurrent parent. The C3074 line had significantly fewer panicles compared to Guangluai 4. The QTL was fine mapped to a $34.4 \mathrm{~kb}$ region on the long arm of chr. 1 and had an negative impact on panicle length, plant height, grain number per panicle, and grain yield per plant compared to Guangluai 4. Begum et al. (2015) found 52 QTLs for yield and other agronomic traits from a GWAS study of 369 elite breeding lines including a major QTL for flowering time on chromosome 3 and major QTL for grain length, width, and length-breadth ratio co-localized on chromosome 7. Another GWAS study by Zhang et al. (2019) using 150 rice landraces found QTL near known yield traits such as SD-1, Hdl, Ghd7, and GW8. To determine the genetics behind each yield component, a QTL mapping study was done to look for chromosomal regions linked to each yield component. Detecting major QTLs for yield traits that are stable across environments would allow researchers to find potential candidate genes that could be used for selection in rice breeding (Collard et al. 2005). 
A QTL mapping study was done using a bi-parental population developed from a cross between 'LaGrue' and 'Lemont' to look for QTLs associated with panicle architecture and yield related traits. The objectives for this project are to; 1) conduct a parental yield study on four U.S. cultivars, LaGrue, Lemont, 'Bengal', 'Mars' to evaluate yield components between each cultivar and to determine which two varieties would be useful in developing a biparental population; 2) conduct a QTL mapping study on panicle architecture and other yield-related traits to detect major QTLs; and 3) identify candidate genes in the major QTL associated with yield traits. The study will provide useful information for breeders to select and develop high yield rice cultivars through marker-assisted selection in rice molecular breeding.

\section{MATERIALS AND METHODS}

\section{Preliminary Yield Study}

A preliminary study was conducted on four US developed tropical japonica cultivars, LaGrue (PI 568891) (Moldenhauer et al., 1994), Lemont (PI 475833) (Bollich et al. 1985), Bengal (PI 561735) (Linscombe et al. 1993), and Mars (Clor 9945) (Johnston et al. 1979) and the goal was to compare yield traits among the four cultivars and to determine which cultivars should be used in the development of a bi-parental population for QTL mapping. The four cultivars were chosen for the study because 1) they frequently serve as parental lines for developing new high yield rice cultivars, and 2) they don't share a common ancestor with each other providing a high degree of genetic diversity between the lines. The four cultivars were evaluated in a randomized complete block design (RCBD) with three replications and two planting dates which were 18 May and 6 June in 2017. The cultivars were planted in seven row $3.7 \mathrm{x} 1.5 \mathrm{~m}$ plots. The planting depth was $1.3 \mathrm{~cm}$ and the spacing between rows was $20.3 \mathrm{~cm}$ apart. The germination date was 26 May for the first planting and 15 June for the second planting. Field management was done according to the standard management in Arkansas. At the harvesting season, 10 plants from each plot were randomly collected from the middle part of each plot excluding the edges of the plot. The plants were harvested for evaluation of 14 agronomic traits (Table 1 or 2). The number of filled seeds/plant were calculated by taking the sum of the number of seeds/panicle counted for each plant. The number of spikelets per plant (sp/pl) were calculated by taking the sum of the number of spikelets counted on each panicle from each plant. Seed weigh/plant was calculated by taking the sum weight of all the filled seed produced from a single plant. Panicle length $(\mathrm{cm})$ was measured by measuring each panicle from the base of the rachis to the tip of the top panicle branch and calculating the average 
102 length for each plant. The number of primary panicle branches/panicle were calculated by counting the number of 103 branches growing from the main rachis from each panicle and calculating the average for each plant. Number of

104 blank seed/panicle (bsp/pan) was calculated by counting the number of blank spikelets on each panicle and 105 calculating the average for each plant. Number of seeds/panicle were measured by counting the number of filled seeds per panicle and taking the average per panicle for each plant. Number of spikelets/panicle were calculated by

107 taking the sum of filled seeds and blank spikelets counted for each panicle and calculating the average per panicle 108 for each plant. Seed weight/panicle was calculated by taking the average seed weight per panicle for each plant. One 109 hundred seed weight/panicle was calculated for each panicle using a formula and calculating the average weight per 110 panicle for each plant. The panicles were dried in a grain drier prior to hand threshing for data collection. The plots 111 in the second planting date were harvested to obtain yield/plot for each cultivar. The seed were dried to $12 \%$

112 moisture and weighed in grams. The results from the parental study showed that LaGrue had the highest overall 113 yield and highest seed count among the cultivars due to higher number of primary panicle branches/panicle (Tables 1141 and 2). LaGrue had a significantly higher number of filled seeds/plant and seed weight/panicle than Mars and 115 Lemont, and a significantly higher number of filled seeds and spikelets/panicle compared to Lemont (Table 1). In 116 contrast, Lemont had a significantly lower number of seed/panicle, number of spikelets /panicle and number of 117 primary branches/panicle but has a longer panicle length then the other three cultivars. Lemont had significantly 118 higher 100-seed weight/panicle and 1000-seed weight/plant than LaGrue and Mars, but significantly lower seed 119 weight/panicle compared to LaGrue and Bengal. Despite having a significantly longer panicle than other cultivars, it 120 did not help with the yield potential of Lemont (Tables 1 and 2). Based on the results, Lemont and LaGrue were 121 selected for the bi-parental study.

\section{Bi-Parental Population Development}

A bi-parental population resulting a cross between LaGrue and Lemont was initiated in the summer 2016.

124 The F1 plants were grown in the spring 2017 in a greenhouse and true F1 plants from selfed plants were identified 125 by means of the molecular study using simple sequence repeat (SSR) markers at the RREC molecular genetics lab.

126 The F2 seed, from each F1 plant, were harvested in the fall 2017 and 322 F2 plants were grown in the greenhouse in 127 the spring 2018 to obtain F2:3 seeds. Meanwhile, the leaf tissue of F2 plants in the greenhouse was sampled for 128 genotypic analysis. 
129

130

131

132

133

134

135

136

137

138

139

140

141

142

143

144

145

146

147

148

149

150

151

152

153

154

\section{Phenotypic Evaluation of F2:3 Families}

In the summer of 2018, 322 F2:3 families derived from the LaGrue $\times$ Lemont F2 population were planted in panicle rows at two locations; RREC $\left(34^{\circ} 28^{\prime} 30.5^{\prime \prime} \mathrm{N} 91^{\circ} 25^{\prime} 07.5^{\prime \prime} \mathrm{W}\right)$ and the University of Arkansas System Division of Agriculture's Pine Tree Research Station (PTRS) near Colt, Arkansas (3507'27.4"N 9055'51.4"W). The two locations were chosen because they both have different soil types (RREC - Crowley silt loam and PTRS Calhoun silt loam) and are located in two major rice-growing regions in the state of Arkansas which have differing environmental conditions, these environments have been utilized for more than 50 years, The families were planted in a randomized complete block design (RCBD) with three replications for each family. The lines were planted at the PTRS on 10 July and RREC on 11 July. Each replication was planted separately in its own block with ten seeds planted for each line. The F2:3 families were evaluated in the field for plant height (PH hereafter) and 50\% heading date (HD hereafter). Plant Height was measured from at least two plants in each row and was measured from the base of the plant to the tip of the main flag leaf to measure the max height of each line when the flag leaf is fully out. Two panicles from each row were sampled to evaluate flag leaf length (FLL hereafter), flag leaf width (FLW hereafter), number of primary panicle branches (PBN hereafter), number of secondary panicle branches (SBN hereafter), and panicle length (PL hereafter). The stand counts at both locations were very low which reduced the amount of panicles and trait measurements collected from the field.

\section{Genotypic Analysis}

The LaGrue $x$ Lemont bi-parental F2 population with 322 plants was genotyped using single nucleotide polymorphism (SNP) markers. Leaf tissue from each F2 plant were freeze dried and sent to Eurofins Scientific Inc. to be genotyped using an Infinium 7K Rice SNP chip. About 832 SNP markers were found to be polymorphic in the two parents of the population distributed along the 12 chromosomes of rice

\section{Statistical Analysis}

Yield traits for the parental yield study were analyzed using JMP Pro 14 software (SAS Institute Inc., Cary, NC). ANOVA analysis followed by a Student's T-test was carried out to compare yield traits between each cultivar. The traits were measured by calculating the average for each plant. One hundred seed weight/panicle and 1000 seed weight/plant were calculated using the formulas below: 
1000 seed weight/plant: $\left(\frac{\text { seed } \frac{\text { weight }}{\text { plant }}}{\text { number of filled } \frac{\text { seeds }}{\text { plant }}}\right) \times 1000$

The F2:3 ANOVA and MANOVA analysis on the population was analyzed using PROC GLM in SAS Pro 9.4 to evaluate genotypic and environmental effects on the traits and correlations between traits. The genotype, location, and genotype $\mathrm{x}$ location were treated as main effects with Replication (Location) treated as random effects. Broad Sense Heritability was calculated using the formula below:

$$
\text { Broad Sense Heritability: } \mathrm{H}^{2}=\left(\frac{\sigma^{2} G}{\sigma^{2} P}\right) \times 100=\left(\left(\sigma^{2} G /\left(\sigma^{2} G+\left(\frac{\sigma^{2} G E}{L}\right)+\left(\frac{\sigma^{2} E}{b L}\right)\right) x 100\right.\right.
$$

Where $\sigma^{2} \mathrm{G}$ : genotypic variance; $\sigma^{2} \mathrm{P}$ : phenotypic variance; $\sigma^{2} \mathrm{GE}$ : genotypic $\mathrm{x}$ environment; $\sigma^{2} \mathrm{E}$ : variance associated with error; L: number of locations or environments; b: number of replications or blocks. The $\sigma^{2} \mathrm{G}, \sigma^{2} \mathrm{GE}$, and $\sigma^{2} \mathrm{E}$ were obtained using the formulas below:

$$
\sigma^{2} \mathrm{E}=\mathrm{MSE}
$$

where MSG is mean square genotype, MSGE is mean square genotype $\mathrm{x}$ location, and MSE is mean square error. The mean square estimates were taken from the ANOVA table in SAS.

\section{QTL Mapping and Candidate Gene Identification}

171 linkage map using kosambi function. Markers were grouped using a LOD threshold of 4.0 and were ordered on the 172 chromosome using the input function where marker order is known from a physical map. Rippling was done using 173 the sum of adjacent LOD scores function (SALOD). QTL mapping was performed using the Inclusive Composite 174 Interval Mapping of additive and dominant QTL function. A minimal LOD score of 2.5 was used for QTL detection 175 and QTL with a LOD score of 3.0 or higher were declared major. The rice genome database Oryzabase was used to 176 search for potential candidate genes previously mapped within major QTL regions detected (Kurata \& Yamazaki, 177 2006). The positive parental allele for each major QTL was done using simple t-test in JMP Pro 14. 
RESULTS

179

180

181

182

183

184

185

186

187

188

189

190

191

192

\section{Phenotypic Analysis of LaGrue x Lemont F2:3 Population}

The phenotypic variations of seven selected traits were observed among the $322 \mathrm{~F}_{2: 3}$ lines for QTL analysis. The results revealed that there was near normal distribution on the F2:3 population for each evaluated trait (Fig 1). The ANOVA showed that "Genotype (G)" had a significant effect on the traits PH and HD; "Environment" had a large influence on PH, HD, and PL; and "G×E interaction" had a large effect on HD. Despite being slightly none significant, the results implied there was G effect on PL (p-value 0.0504) (Table 4). Further analysis showed that PH had high broad sense heritability for the trait with 0.7 , indicating that the PH was highly heritable (Table 4, Fig.1). The results showed that the SBN $(\mathrm{CV}=22.7)$ and $\mathrm{HD}(\mathrm{CV}=6)$ had the highest and lowest coefficient of variation values, respectively, indicating the largest variation existed in these two traits compared to the other traits measured from the population (Table 4). MANOVA analysis found strong significant correlations between FLL, PL, PBN, and SBN (Table 5). The strongest correlations were found between SBN with PBN (0.63) and PL (0.61). Flag leaf length was strongly correlated with PL, PBN and SPN. Panicle length was also strongly correlated with PBN and SPN. These results show there may be favorable loci in the population that are involved in both panicle development and flag leaf development. It is noteworthy that no negative correlation between the measured traits was found.

\section{QTL Detected for Yield Traits in $\mathbf{F}_{2: 3}$ population}

\section{Flag leaf length and width}

To conduct the QTL analysis, the genotypic analysis of 7000 SNP markers were ordered onto a linkage map using kosambi function. A total of 24 QTLs, including 13 major QTLs (LOD>3.0) and 9 minor QTLs, for seven traits were detected in both LaGrue and Lemont and were distributed on 5 chromosomes of 1, 2, 7, 8, and 9. Of 24 detected QTLs, 11 that were found in in LaGrue and the 13 QTLs in Lemont (Table 6). Five different QTLs positioned in two similar genomic regions, $q \mathrm{PH} 1-3$ associated with the $\mathrm{PH}$ trait positioned the same genomic region as $q S B N 1-2$ at chr.1, and $q F L L 8$ associated with the FLL trait share the same genomic position with $q P L 8-2$ associated with $P H t$ and $q H D 8$ associated with HD (Table 6). Three major and one minor QTL were detected for PH trait on chr. 1 and 8 with three QTLs on chr.1 (Table 6). Two QTLs, $q$ PH1-2 and $q$ PH1-3, were co-localized in the same chromosomal position for both Stuttgart and Pine Tree locations with both having very high LOD values of 
17.38 and 54.38, respectively (Fig. 2 and 3), and together explained $87 \%$ of phenotypic variation. This shows that there might be a major gene that controls plant height in the region. All the QTLs except for the minor QTL, $q$ PH11, that increased plant height originated from LaGrue. Five QTLs including two major and three minor QTLs for HD trait were detected on chr. 1, 2, 7, and 8 each with one QTL and two QTLs on chr. 7 (Table 6, Fig.s 2 and 3). Two major QTLs, $q H D 1$ and $q H D 8$, explained about $11.75 \%$ and $7.23 \%$ of phenotypic variation, respectively. Furthermore, all these QTLs were linked to the Lemont allele which delayed heading date. Seven QTLs including five major and two minor QTLs for PL were detected on chr. 1, 7, 9 each with one QTL and chr. 2 and 8 each with two QTLs (Table 6, Fig.s 2 and 3). Two QTLs on chr. 8 qPL8-1 and $q$ PL8-2 positioned near each other on chr. 8 explained $18.5 \%$ of phenotypic variation in the population. LaGrue was the major contributor to increased panicle length in $q P L 1, q P L 2-1$, and $q P L 2-2$ while Lemont was the major contributor in $q P L 8-1$, and $q P L 8-2$ (Table 6, Fig.s 2 and 3). One major QTL for number of primary panicle branches $q P B N 1$ was detected on chr. 1 where LaGrue was the positive parental allele (Fig. 3). Three QTLs including one major and two minor QTLs for SBN trait were detected on chr. 1 and 9 with two QTLs on chr. 1 (Table 6). The major QTL, qSBN1-1, explained about 16.3\% of phenotypic variation and had a positive allele from LaGrue that increased the number of secondary branches per panicle. The QTL $q S B N 1-1$ and $q S B N 1-2$ were detected near each other on chr. 1 (Table 6, Fig.s 2 and 3). Three QTLs for the FLL trait including 1 major and 2 minor QTLs were detected. The major QTL qFLL8 located on chr.8 explained about $8 \%$ of the phenotypic variation and had positive allele with Lemont One major QTL, $q F L W 2$, for FLW was detected on chr. 2 explaining 9.21\% of phenotypic variation in the population (Table 6, Fig.s 2 and 3).

\section{Candidate Gene Analysis}

Using the online rice database Oryzabase, a total of 9 candidate genes were found with two genes on chr.1 and seven genes on chr.8 controlling plant height, panicle development, and flag leaf size (Table 7). The genes on chr.1 are semi-dwarf $1(s d-1)$ and $D C L 3 a$. (Table 7). A previous study reports the importance of this location on plant height since the semi-dwarf $s d-1$ locus encodes a defective 20-oxidase GA biosynthesis enzyme involved in the synthesis of gibberellin located in the two QTL $q P H 1-3$ and $q$ PH1-4 (Sasaki et al. 2002). The DCL3a gene is a Dicer-like 3 homolog located near $q P B N 1$ that produces a 24-nt small interfering RNA (Wei et al., 2014). The gene was found to control plant height as well as panicle development. 
The genes found on chr.8 are UBP1-5, UBP1-8, Wide and Thick Grain 1 (WTG1), OsSPL16, OsSPL14,

231

232

233

234

OsCOL15, and OsMADS7 (Table 7). UBP1-5 and UBP1-8 are ubiquitin carboxyl-terminal hydrolase genes that were found to be significantly upregulated during panicle development (Ke et al. 2018). WTG1 is a gene that encodes an otubain-like protease with deubiquitination activity (Huang et al. 2017). The gene was found to control panicle development affecting the number of primary and secondary branches and also number of seed per panicle. The gene was also found to control OsSPL14 through degradation of K63-linked ubiquitin chains of the protein (Wang et al. 2017) The gene OsSPL14, otherwise known as Wealthy Farmer's Panicle, encodes a SQUAMOSA PROMOTER BINDING PROTEIN-LIKE 14 protein and is located in the QTL $q$ PL8-1 (Miura et al., 2010). The gene was found to control number of primary and secondary branches per panicle, tiller number, flag leaf size, plant height, grain yield, number of seeds per panicle, 1000-grain weight, and lodging resistance. OSSPL16 is a squamosa promoter-binding protein transcription factor associated with grain size and 1000 grain weight (Wang et al. 2012, 2015). The gene was also found to control another gene involved in grain size $G W 7$ through binding to the promoter and inhibition gene expression (Wang et al. 2015). OsCOL15 is a CONSTANS-like transcription factor located in the QTL $q H D 8$ that regulates flowering time by influencing flowering genes and acts as a floral inhibitor (Wu et al. 2018). OsMADS7 (or otherwise known as OsMADS45) is a MADS-box class-E class gene which controls flowering as well as plant height, tiller number, number of spikelets per panicle, and grain yield (Cui et al. 2013; Wang et al., 2013). The gene was found to influence flowering genes RFT1, Hd3a, OsMADS14, and OsMADS18 in controlling flowering time.

\section{Discussion}

Increasing rice seed yield is the outmost goal in rice breeding program. a high yielding rice cultivar is developed from parental lines with favorable agronomic characteristics such as LaGrue and Lemont that have been used frequently for developing high yield cultivars in the U.S. Moreover, identification of QTLs controlling favorable agronomic characteristics in LaGrue and Lemont would be valuable for the breeding of high-yielding rice cultivsrs. Lemont and LaGrue were evaluated on several agronomic traits associated with yield. Many QTLs associated with seed yield production have been identified and applied in rice breeding programs (Miura et al., 2011). Plant height is one important trait since tall rice plants tend to lodge easier that short ones. The results showed $q P H 1-2$ and $q P H 1-3$, were adjacent to each other on chr. 1 and explained a significant phenotypic variation 
257 in the population. The trait was highly heritable in the population having a broad sense heritability of 0.70 . Our result is supported by previous efforts by IRRI (1967) that integrated a recessive semi-dwarf gene (sd-1), which was found earlier in China, as well as genomic detection of $s d-1$ (Monna et al, 2001; Sasaki et al. 2002) that is colocalized by the detected QTLs. The gene causes a semi-dwarf height in rice without affecting grain yield. The semi-dwarf height also decreases the chance of lodging in rice increasing the potential harvestable yield of rice cultivars. The gene was very important in Asia in the development of high-yielding rice cultivars with reduced susceptibility to lodging (Sasaki et al., 2002). The gene $s d-1$ gene came from Lemont since LaGrue does not have the gene $s d-1$.

Panicle traits, including panicle length, primary branch number, secondary branch number, and spikelet number, are considered as some of the most important components in seeds yield production (Cheng et al. 2007; Peng et al. 2014; Shang et al. 2020). Increasing panicle size has a positive correlation with other panicle traits as well as FLL and $\mathrm{HD}$, and as a result, it can be assumed that increasing any of these panicle characteristics such as panicle size can improve seed yield production. Our assumption is supported by a previous study by Shang et al., (2020) Also the QTL analysis showed that those QTLs with higher phenotypic variation originated from LaGrue which had the longer panicle. On chr. 8, major QTLs for PL and FLL were co-localized in a 3.2Mbp region, so it can be assumed the positive correlation between PL and FLL resulted in this relationship. All the major QTLs which increased FLL and PL on chr. 8 came from Lemont. Five potential candidate genes for the traits UBPI-5, UBPI-8, Wide and Thick Grain 1 (WTG1), OSSPL16 and OSSPL14 were found in these QTL regions. The genes UBP1-5, UBP1-8 were found to be upregulated during panicle development (Ke et al. 2018). Wide and Thick Grain 1 (WTGl) is a gene that affect grain size, panicle architecture, 1000 seed weight, and flag leaf width (Huang et al. 2017). This gene was found to interact with another gene in the region OsSPL14 or otherwise known as Wealthy Farmer's Panicle (Wang et al. 2017) OSSPL14 induces an ideal plant architecture such as increased number of primary and secondary branches, increased number of seeds per panicle, increase in length of flag leaf length and reduced lodging. Reduced gene expression of WTG1 was found to increase the expression of OSSPL14 giving an ideal plant type in rice (Huang et al. 2017). OsSPL16 controls grain size, panicle branching, and 1000 grain weight and may control grain size through regulation of $g w 7$ (Wang et al. 2012, 2015). Because there is a positive correlation, analysis showed that FLL and PL, PNB, and SNB, could be genes such as OsSPL14 and WTG1 and therefore, could be potential targets for molecular breeding. One major QTL for FLW was found on chr. 2 that came from Lemont that increased leaf width. 
285

286

287

288

289

290

291

292

293

294

295

296

297

298

299

300

301

302

303

304

305

306

307

308

309

Gramene search found previous reports that found a QTL that overlapped the panicle length QTL $q P L-1$ on chr. 1 (Thomson et al. 2003; Hittalmani et al. 2002, 2003; Septiningsih et al. 2003). Two reports also found QTL, qPL2-2, and $q P L 7$, that overlapped the QTL regions for $q P L 2-1, q P L 2-2$, and $q P L 7-1$ (Mei et al. 2003, 2005).

Five QTL for heading date were detected on chr. 1,2,7, and 8 with one major QTL $q H D 1$ explaining $11.76 \%$ of phenotypic variation in the population. All the major QTL for heading date came from Lemont which increased days to heading. Two candidate genes for heading date were detected in qHD8; OsCOL15 and OsMADS7. OsCOL15 is a floral inhibitor that delays the days to heading in rice (Wu et al. 2018). The gene influences heading date by upregulating the flowering gene $G h d 7$ and inhibiting $R I D I$ which in turn influences other genes such as Ehdl, Hd3a, and RFT1. OsMADS7 is another flowering gene that participates in regulation of floral development (Cui et al. 2010). The gene has been found to control flowering as well as plant height, panicle length, tiller number, number of spikelets per panicle, and grain yield (Wang et al. 2013) The gene was found to control four other genes, RFT1, Hd3a, OsMADS14, and OsMADS18 which may contribute to flowering and vegetative growth (Wang et al. 2013) Whereas the gene is found to control panicle length and number of spikelets per panicle, it could be considered a candidate gene for yield traits as it is found in the same regions as $q P L 8-2$ and $q F L L 8-2$. Reports from other studies found QTL for heading date that overlapped with the QTL region for $q H D 1$ (Li et al. 2003; Hittalmani et al. 2003; Thomson et al. 2003). Surprisingly, the heritability for heading date was low with a broad-sense heritability of 0.21 .

Three QTLs for SBN were found on chr. 1 and 9. Two QTLs, $q S B N 1-1$ and $q S B N 1-2$, were found close together on chr. 1 with $q S B N 1-1$ having the highest LOD and was responsible for $16.3 \%$ of phenotypic variation in the population. One major QTL for PBN was found on chr. 1. The major QTL for primary and secondary branch number $q P B N 1$ and $q S B N 1-2$, were found to come from LaGrue which increased the number of panicle branches. This was expected considering LaGrue produces a significantly higher number of seed than Lemont. One candidate gene DCL3a was found near $q P B N 1$ that was found to control both PBN and SBN (Wei et al. 2014)

\section{CONCLUSION}

Improving grain yield in rice is one of the important goals in rice breeding programs. Overall grain yield in rice is dependent on several yield components such as plant height, number of seeds per panicle, and 1000 seed 
311 weight (Xing et al., 2010). The detection of major QTL for yield components can be beneficial for breeding of high-

312 yielding rice varieties. Results from this study showed major QTLs for PH, FLL, PL, PNB, SNB traits were found.

313 The results from this study can be used by breeders for selecting superior lines via marker assisted selection.

314

315

316

317

318

319

320

321

322

323

324

325

326

327

328

329

330

331

332

333

334

335

336

337

338

339

340

341

342

343

344

345

346

347

348

349

350

351

352

353

354

355

356

357

358 
References

Akinwale MG, Gregorio G, Nwilene F, Akinyele BO, Ogunbayo SA, Odiyi AC (2011) Heritability and correlation coefficient analysis for yield and its components in rice (Oryza sativa L.). African Journal of plant science. 5(3):207-212.

Alamin M, Zeng D, Qin R, Sultana MH, Jin X, Shi C (2017) Characterization and fine mapping of SFL1, a gene controlling screw flag leaf in rice. Plant Molecular Biology Reporter. 35(5):491-503. doi:10.1007/s11105-017-1039-x

Ashikari M, Matsubara A, Kitano H, Miura K, Ito M, Asano K et al (2010) OsSPL14 promotes panicle branching and higher grain productivity in rice. Nature Genetics. 42(6):545-549. doi:10.1038/ng.592

Begum H, Spindel JE, Lalusin A, BorromeoT, Gregorio G, Hernandez J, et al. (2015) Genome-Wide Association Mapping for Yield and Other AgronomicTraits in an Elite Breeding Population of Tropical Rice (Oryza sativa). PLoS ONE 10(3): e0119873.doi:10.1371/journal.pone.0119873

Bollich CN, Webb BD, Marchetti MA, Scott JE (1985) Registration of 'Lemont'rice. Crop Science. 25(5).:883-885

Cheng FM, Zhang QF, Zhu HJ, Zhao NC, Wang F, Chen KM, Zhang GP (2007) The difference in amylose content within a panicle as affected by the panicle morphology of rice cultivars. J Cereal Sci 46(1):49-57 doi: https://www.sciencedirect.com/science/article/abs/pii/S0733521006001883

Collard BCY, Jahufer MZZ, Brouwer JB, Pang ECK (2005) An introduction to markers, quantitative trait loci (QTL) mapping and marker-assisted selection for crop improvement: The basic concepts. Euphytica. 142(1):169-196. doi:10.1007/s10681-005-1681-5

Cui R, Han J, Zhao S, Su K, Wu F, Du X et al (2010) Functional conservation and diversification of class E floral homeotic genes in rice (oryza sativa). The Plant Journal. 61(5):767-781. doi:10.1111/j.1365313X.2009.04101.X

Devi KR, Chandra BS, Lingaiah N, Hari Y, Venkanna V (2017) Analysis of variability, correlation and path coefficient studies for yield and quality traits in rice (Oryza Sativa L.). Agricultural Science Digest-A Research Journal. 37(1):1-9

Guo T, Chen K, Dong N, Shi C, Ye W, Gao J et al (2018) Grain size and number1 negatively regulates the OsMKKK10-OsMKK4-OsMPK6 cascade to coordinate the trade-off between grain number per panicle and grain size in rice. The Plant Cell. 30(4):871-888. doi:10.1105/tpc.17.00959

Gupta P, Naithani S, Tello-Ruiz MK, Chougule K, D'Eustachio P, Fabregat,A et al (2016) Gramene database: Navigating plant comparative genomics resources. Current Plant Biology.7-8(C):10-15. d oi:10.1016/j.cpb.2016.12.005

Han Z, Hu W, Tan C, Xing Y (2017) QTLs for heading date and plant height under multiple environments in rice. Genetica, 145(1): 67-77. doi:10.1007/s10709-016-9946-6

Hardke J (2018) Introduction. In: J Hardke, L Goforth (ed) Rice Production Handbook.. University of Arkansas Cooperative Extension Service Center Print Media, Little Rock, Arkansas, pp 1-9

Hardke J (2019) Rice Production in Arkansas. University of Arkansas Division of Agriculture Research and Extension. https://www.uaex.edu/farm-ranch/crops-commercial-horticulture/rice/

Hittalmani S, Shashidhar HE, Bagali PG, Huang N, Sidhu JS, Singh VP, Khush GS (2002) Molecular mapping of quantitative trait loci for plant growth, yield and yield related traits across three diverse locations in a doubled haploid rice population. Euphytica. 125(2).:207-214. doi:10.1023/A:1015890125247

Hittalmani S, Huang N, Courtois B, Venuprasad R, Shashidhar HE, Zhuang, J et al (2003) Identification of QTL for 
427

428

429

430

431

432

433

434

435

436

437

438

439

440

441

442

443

444

445

446

447

448

449

450

451

452

453

454

455

456

457

458

459

460

461

462

463

464

465

466

467

468

469

470

growth- and grain yield-related traits in rice across nine locations of asia. Theoretical and Applied Genetics. 107(4).:679-690. doi:10.1007/s00122-003-1269-1

Huang K, Wang D, Duan P, Zhang B, Xu R, L, N, Li Y (2017) WIDE AND THICK GRAIN 1, which encodes an otubain-like protease with deubiquitination activity, influences grain size and shape in rice. The Plant Journal. 91(5):849-860. doi:10.1111/tpj.13613

International Rice Research Institute (1967) Annual Report for 1966,59-82

Jang S, Lee Y, Lee G, Seo J, Lee D, Yu Y et al (2018) Association between sequence variants in panicle development genes and the number of spikelets per panicle in rice. BMC Genetics. 19(1). 5-11. doi:10.1186/s12863-017-0591-6

Johnston TH, Wells BR, Marchetti MA, Lee FN, Henry SE (1979) Registration of 'Mars' Rice'. Crop Science. 19(5):743. doi:10.2135/cropsci1979.0011183X001900050058x

Kato T (1989). Relationship between grain-filling process and sink capacity in rice (Oryza sativa L.). Japanese Journal of Breeding. 39(4).:431-438.

Kurata N, \& Yamazaki Y (2006) Oryzabase. an integrated biological and genome information database for rice. Plant Physiology. 140(1):12-17. doi:10.1104/pp.105.063008

Ke S, Liu X, Luan X, Yang W, Zhu H, Liu G et al (2018) Genome-wide transcriptome profiling provides insights into panicle development of rice (oryza sativa L.). Gene. 675:285-300. doi:10.1016/j.gene.2018.06.105

Li ZK, Yu SB, Lafitte HR, Huang N, Courtois B, Hittalmani S et al (2003) QTL $\times$ environment interactions in rice. I. heading date and plant height. Theoretical and Applied Genetics, 108(1):141-153. doi:10.1007/s00122$003-1401-2$

Linscombe SD, Jodari F, McKenzie KS, Bollich PK, White LM, Groth DE, Dunand RT (1993) Registration of 'Bengal' rice. Crop Science. 33(3):645. doi:10.2135/cropsci1993.0011183X003300030046x

Mei HW, Luo LJ, Ying CS, Wang YP, Yu XQ, Guo LB et al (2003). Gene actions of QTLs affecting several agronomic traits resolved in a recombinant inbred rice population and two testcross populations. Theoretical and Applied Genetics, 107(1): 89-101. doi:10.1007/s00122-003-1192-5

Mei HW, Li ZK, Shu QY, Guo LB, Wang YP, Yu XQ et al (2005). Gene actions of QTLs affecting several agronomic traits resolved in a recombinant inbred rice population and two backcross populations. Theoretical and Applied Genetics. 110(4):649-659. doi:10.1007/s00122-004-1890-7

Meng, L., Li, H., Zhang, L., \& Wang, J. (2015). QTL IciMapping: Integrated software for genetic linkage map construction and quantitative trait locus mapping in biparental populations. The Crop Journal, 3(3):269-283. doi:10.1016/j.cj.2015.01.001

Miura K, Ikeda M, Matsubara A, Song X, Ito M, Asano K et al (2010) OsSPL14 promotes panicle branching and higher grain productivity in rice. Nature Genetics. 42(6):545-9. Retrieved from https://search.proquest.com/docview/366635681?accountid=8361

Miura K, Ashikari M, Matsuoka M (2011) The role of QTLs in the breeding of high-yielding rice. Trends Plant Sci 16(6):319-326

Moldenhauer K A K, Gravois KA, Lee FN, Norman RJ, Bernhardt JL, Wells BR, Blocker MM (1994) Registration of 'LaGrue'rice. Crop science.34(4):1123-1124. Doi:

https://www.sciencedirect.com/science/article/abs/pii/S1360138511000446

Monna, L., Kitazawa, N, Yoshino, R, Suzuki, J , Masuda, H., Maehara et al. (2002). Positional cloning of rice 
471

472

473

474

475

476

477

478

479

480

481

482

483

484

485

486

487

488

489

490

491

492

493

494

495

496

497

498

499

500

501

502

503

504

505

506

507

508

509

510

511

512

513

514

515

516

517

518

519

520

521

522

523

524

525

526

semidwarfing gene, sd-1: rice "green revolution gene" encodes a mutant enzyme involved in gibberellin synthesis. DNA research, 9(1), 11-17 doi: https://academic.oup.com/dnaresearch/article/9/1/11/514548?login=true

Peng SB, Khush GS, Virk P, Tang QY, Zou YB (2008) Progress in ideotype breeding to increase rice yield potential. Field Crops Res 108(1):32-38 doi: https://www.sciencedirect.com/science/article/abs/pii/S0378429008000749

Peng Y, Gao Z, Zhang B, Liu C, Xu J, Ruan B et al (2014) Fine mapping and candidate gene analysis of a major QTL for panicle structure in rice. Plant Cell Reports, 33(11):1843-1850. doi:10.1007/s00299-014-1661-0

Rice productivity. Ricepedia. http://ricepedia.org/rice-as-a-crop/rice-productivity

Samonte SOP, Samonte SOP, Wilson LT, Wilson LT, McClung AM (1998) Path analyses of yield and yield-related traits of fifteen diverse rice genotypes. Crop Science. 38(5):1130-1136. doi:10.2135/cropsci1998.0011183X003800050004x

Sasaki A, Ashikari M, Ueguchi-Tanaka M, Itoh H, Nishimura A, Swapan D et al (2002) A mutant gibberellinsynthesis gene in rice. Nature. 416(6882):701-702. doi:10.1038/416701a

Septiningsih EM, Prasetiyono J, Lubis E, Tai TH, Tjubaryat T, Moeljopawiro S, McCouch SR (2003) Identification of quantitative trait loci for yield and yield components in an advanced backcross population derived from the oryza sativa variety IR64 and the wild relative O. rufipogon. Theoretical and Applied Genetics 107(8): 1419-1432. doi:10.1007/s00122-003-1373-2

Shang F, Chen L, Meng X, Yang K, Wang J (2020). Fine mapping and grain yield analysis of a major QTL controlling primary branch number in rice (Oryza sativa L.). Genetic Resources and Crop Evolution, 67(2): 421-431 doi: https://link.springer.com/article/10.1007/s10722-019-00857-8

Sun Z, Yin X, Ding J, Yu D, Hu M, Sun X et al (2017) QTL analysis and dissection of panicle components in rice using advanced backcross populations derived from oryza sativa cultivars HR1128 and 'nipponbare'. PloS One. 12(4). e0175692. doi:10.1371/journal.pone.0175692

The Importance of Rice. International Rice Research Institute. http://www.knowledgebank.irri.org/ericeproduction/Importance_of_Rice.htm

Thomson MJ, Tai TH, McClung AM, Lai X, Hinga ME, Lobos KB et al (2003) Mapping quantitative trait loci for yield, yield components and morphological traits in an advanced backcross population between oryza rufipogon and the oryza sativa cultivar jefferson. Theoretical and Applied Genetics. 107(3):479-493. doi:10.1007/s00122-003-1270-8

Wang S, Wu K, Yuan Q Liu,X, Liu Z, Lin X et al (2012) Control of grain size, shape and quality by OsSPL16 in rice. Nature Genetics. 44(8):950-954. doi:10.1038/ng.2327

Wang J, Lo S, Li Y, Chen P, Lin S, Ho T et al (2013) Ectopic expression of OsMADS45 activates the upstream genes Hd3a and RFT1 at an early development stage causing early flowering in rice. Botanical Studies. 54(1):1-13. doi:10.1186/1999-3110-54-12

Wang S, Li S, Liu Q, Wu K, Zhang J, Wang S et al (2015) The OsSPL16-GW7 regulatory module determines grain shape and simultaneously improves rice yield and grain quality. Nature Genetics. 47(8):949-954. doi:10.1038/ng.3352

Wang S, Wu K, Qian Q, Liu Q, Li Q, Pan Y et al (2017) Non-canonical regulation of SPL transcription factors by a human OTUB1-like deubiquitinase defines a new plant type rice associated with higher grain yield. Cell Research. 27(9):1142-1156. doi:10.1038/cr.2017.98

Wei L, Gu L, Song X, Cui X, Lu Z, Zhou M et al (2014) Dicer-like 3 produces 
transposable element-associated 24-nt siRNAs that control agricultural traits in rice. Proceedings of the National Academy of Sciences of the United States of America. 111(10): 3877-3882. doi:10.1073/pnas.1318131111

Wu W, Zhang Y, Zhang M, Zhan X, Shen X, Yu P et al (2018). The rice CONSTANS-like protein OsCOL15 suppresses flowering by promoting Ghd7 and repressing RID1. Biochemical and Biophysical Research Communications. 495(1):1349-1355. doi:10.1016/j.bbrc.2017.11.095

Xing Y, Zhang Q (2010) Genetic and molecular bases of rice yield. Annual Review of Plant Biology. 61(1):421-442. doi:10.1146/annurev-arplant-042809-112209

Zhang L, Wang J. Wang J, Wang L, Ma,B, Zeng, L et al (2015) Quantitative trait locus analysis and fine mapping of the qPL6 locus for panicle length in rice. Theoretical and Applied Genetics. 128(6): 11511161. doi:10.1007/s00122-015-2496-y

Zhang P, Zhong K, Zhong Z, Tong H (2019) Genome-wide association study of important agronomic traits within a core collection of rice (oryza sativa L.). BMC Plant Biology. 19(1): 259-259. doi:10.1186/s12870019-1842-7

Zhou S, Zhu, M, Wang F, Huang J, Wang G (2013) Mapping of QTLs for yield and its components in a rice recombinant inbred line population. Pakistan Journal of Botany. 45(1):183-189

Zhu J, Zhu J, Zhou Y, Zhou Y, Liu Y, Liu, Y, Liang G (2011) Fine mapping of a major QTL controlling panicle number in rice. Molecular Breeding. 27(2): 171-180. doi:10.1007/s11032-010-9420-6 
Table1: Comparisons of yield traits among four cultivars.

\begin{tabular}{|c|c|c|c|c|}
\hline Trait & LaGrue & Lemont & Bengal & Mars \\
\hline No. filled seeds/plant & $1812.9^{\mathrm{a}}$ & $1277.4^{\mathrm{b}}$ & $1428.7^{\mathrm{ab}}$ & $1333.1^{b}$ \\
\hline No. spikelets/plant & $2078.8^{\mathrm{a}}$ & $1405.2^{\mathrm{b}}$ & $1874.4^{\mathrm{ab}}$ & $1735.3^{\mathrm{ab}}$ \\
\hline $\begin{array}{l}\text { No. blank } \\
\text { spikelets/plant }\end{array}$ & $264.3^{\mathrm{b}}$ & $127.7^{\mathrm{c}}$ & $445.3^{\mathrm{a}}$ & $402.6^{\mathrm{a}}$ \\
\hline Seed weight/ plant, g & $43.4^{\mathrm{a}}$ & $34.2^{\mathrm{ab}}$ & $37.5^{\mathrm{ab}}$ & $31.2^{\mathrm{b}}$ \\
\hline $\begin{array}{l}1000 \text { seed } \\
\text { weight/Plant }\end{array}$ & $24.0^{\mathrm{b}}$ & $26.5^{\mathrm{a}}$ & $26.1^{\mathrm{a}}$ & $23.3^{\mathrm{b}}$ \\
\hline Panicle Length, $\mathrm{cm}$ & $19.9^{\mathrm{b}}$ & $20.8^{\mathrm{a}}$ & $20.1^{\mathrm{ab}}$ & $20.1^{\mathrm{ab}}$ \\
\hline $\begin{array}{l}\text { No. primary panicle } \\
\text { branches/panicle }\end{array}$ & $11.9^{\mathrm{a}}$ & $10.8^{\mathrm{b}}$ & $11.1^{\mathrm{b}}$ & $11.3^{\mathrm{b}}$ \\
\hline $\begin{array}{l}\text { No. filled } \\
\text { seeds/panicle }\end{array}$ & $121.7^{\mathrm{a}}$ & $88.7^{b}$ & $113.7^{\mathrm{a}}$ & $113.7^{\mathrm{a}}$ \\
\hline \# spikelets/panicle & $139.1^{\mathrm{a}}$ & $98.0^{\mathrm{b}}$ & $148.3^{\mathrm{a}}$ & $147.4^{\mathrm{a}}$ \\
\hline $\begin{array}{l}\text { No. blank } \\
\text { spikelets/panicle }\end{array}$ & $17.4^{\mathrm{b}}$ & $9.2^{\mathrm{c}}$ & $34.7^{\mathrm{a}}$ & $36.3^{\mathrm{a}}$ \\
\hline $\begin{array}{l}\text { 100-seed } \\
\text { weight/panicle, g }\end{array}$ & $2.4^{\mathrm{b}}$ & $2.6^{\mathrm{a}}$ & $2.6^{\mathrm{a}}$ & $2.3^{\mathrm{c}}$ \\
\hline Seed weight/panicle, $g$ & $2.9^{\mathrm{a}}$ & $2.4^{\mathrm{b}}$ & $3.0^{\mathrm{a}}$ & $2.6^{\mathrm{b}}$ \\
\hline No. tillers/Plant & $14.0^{\mathrm{ab}}$ & $14.6^{\mathrm{a}}$ & $11.4^{\mathrm{b}}$ & $12.3^{\mathrm{ab}}$ \\
\hline No. panicles/Plant & $13.8^{\mathrm{ab}}$ & $14.5^{\mathrm{a}}$ & $11.1^{\mathrm{b}}$ & $12.0^{\mathrm{ab}}$ \\
\hline
\end{tabular}


Table 2: Evaluation of plot yield between rice cultivars

575

576

577

578

579

580

581

582

\begin{tabular}{lccc}
\hline Cultivar & $\begin{array}{l}\text { Average yield } \\
\text { per plot (g) }\end{array}$ & $\begin{array}{l}\text { Yield difference } \\
\text { compared to LaGrue }\end{array}$ & $\begin{array}{l}\text { Percentage } \\
\text { yield } \\
\text { increase of } \\
\text { LaGrue } \\
(\%)\end{array}$ \\
\hline LaGrue & 2004.47 & 0 & 0 \\
Bengal & 1883.37 & -121.1 & 6 \\
Lemont & 1693.17 & -311.3 & 15.5 \\
Mars & 1572.87 & -431.6 & 21.5 \\
\hline
\end{tabular}

583

584

585

586

587

588

589

590

591

592

593

594

595

596

597

598

599

600

601 
Table 3: Yield Analysis of Parental Controls and descriptive statistics of the $F_{2: 3}$ Population

604

\begin{tabular}{|c|c|c|c|c|c|c|c|}
\hline Trait $\dagger$ & $\begin{array}{l}\text { LaGrue } \\
\text { Meant }\end{array}$ & $\begin{array}{l}\text { Lemont } \\
\text { Mean } \\
\end{array}$ & $\begin{array}{l}\text { Mean } \\
(\mathrm{cm})\end{array}$ & $\begin{array}{l}\text { Range } \\
(\mathrm{cm})\end{array}$ & $\begin{array}{l}\text { Standard Dev. } \\
\text { (SD) }\end{array}$ & $\begin{array}{l}\text { Standard } \\
\text { Err. (SE) }\end{array}$ & $\mathrm{CV}$ \\
\hline $\mathrm{PH}(\mathrm{cm})$ & $101^{\mathrm{a}}$ & $90^{\mathrm{b}}$ & 99.1 & $\begin{array}{l}66.5- \\
136.5\end{array}$ & 11.8 & 0.33 & 11.8 \\
\hline HD (day) & $79.8^{\mathrm{a}}$ & $82^{\mathrm{a}}$ & 79.4 & $69-94$ & 4.8 & 0.14 & 6 \\
\hline FLL(cm) & $26.3^{\mathrm{a}}$ & $28.3^{\mathrm{a}}$ & 27.5 & $16.4-46.8$ & 4.4 & 0.13 & 16.2 \\
\hline $\mathrm{FLW}(\mathrm{cm})$ & $1.2^{\mathrm{a}}$ & $1.3^{\mathrm{a}}$ & 1.2 & $0.6-1.9$ & 0.2 & 0.0059 & 16.9 \\
\hline $\mathrm{PL}(\mathrm{cm})$ & $23^{\mathrm{a}}$ & $23.9^{\mathrm{a}}$ & 23.3 & $16.8-31.8$ & 2.4 & 0.068 & 10.1 \\
\hline PBN & $23.2^{\mathrm{a}}$ & $23.3^{\mathrm{a}}$ & 23.1 & $12.0-34.0$ & 3.5 & 0.1 & 14.9 \\
\hline SBN & $36.6^{\mathrm{a}}$ & $34^{\mathrm{a}}$ & 37.7 & $14-68.5$ & 8.6 & 0.25 & 22.7 \\
\hline
\end{tabular}

$605 \uparrow$ Traits; PH, plant height; HD, Days of heading; FLL, Flag leaf length; Flag leaf width; PL, Panicle length; PBN,

606 Number of primary branches; SBN, Number of secondary branches

$607 \$$ Significance of 0.05 given by abc subscript

608

609

610

611

612

613

614

615

616

617

618

619

620

621

622

623

624

625

626 
627

628

629

630

631

632

633

634

635

636

637

638

639

640

641

642

643

644

645

646

647

648

649

650

651

652

653

654

655

656

657

658

659

660

\begin{tabular}{|c|c|c|c|c|c|}
\hline Trait & Genotype: & Location $\S$ & $\begin{array}{l}\text { Genotype } \mathrm{x} \\
\text { Location }\end{array}$ & $\begin{array}{c}\text { Mean } \\
\text { Square Err. }\end{array}$ & Heritability \\
\hline $\mathrm{PH}(\mathrm{cm})$ & $\begin{array}{c}209.82^{* * *} \\
<.0001\end{array}$ & $\begin{array}{l}19829 * \\
0.0084\end{array}$ & $\begin{array}{c}62.91 \\
0.4254\end{array}$ & 61.65 & 0.7 \\
\hline HD (day) & $\begin{array}{c}17.87 * * \\
0.0001\end{array}$ & $\begin{array}{c}5196.40 * \\
0.0087\end{array}$ & $\begin{array}{l}14.24 * \\
0.0436\end{array}$ & 11.62 & 0.21 \\
\hline FLL $(\mathrm{cm})$ & $\begin{array}{c}20.88 \\
0.2616\end{array}$ & $\begin{array}{c}3.49 \\
0.7404\end{array}$ & $\begin{array}{l}19.063 \\
0.5834\end{array}$ & 19.62 & 0.08 \\
\hline $\mathrm{FLW}(\mathrm{cm})$ & $\begin{array}{c}0.038 \\
0.1153\end{array}$ & $\begin{array}{c}1.39 \\
0.3199\end{array}$ & $\begin{array}{c}0.030 \\
0.8263\end{array}$ & 0.033 & 0.19 \\
\hline $\mathrm{PL}(\mathrm{cm})$ & $\begin{array}{c}4.95 \\
0.0504\end{array}$ & $\begin{array}{c}688.65^{*} \\
0.0007\end{array}$ & $\begin{array}{c}4.14 \\
0.5429\end{array}$ & 4.21 & 0.17 \\
\hline PBN & $\begin{array}{c}11.65 \\
0.3092\end{array}$ & $\begin{array}{l}227.44 \\
0.2513\end{array}$ & $\begin{array}{c}9.67 \\
0.8612\end{array}$ & 11.1 & 0.27 \\
\hline SBN & $\begin{array}{c}78.38 \\
0.0516\end{array}$ & $\begin{array}{l}545.34 \\
0.2764\end{array}$ & $\begin{array}{c}64.58 \\
0.6002\end{array}$ & 66.81 & 0.17 \\
\hline
\end{tabular}

Table 4: ANOVA analysis of yield traits in $\mathrm{F}_{2: 3}$ population

$\dagger$ Traits; PH, plant height; HD, Days of heading; FLL, Flag leaf length; Flag leaf width; PL, Panicle length; PBN, Number of primary branches; SBN, Number of secondary branches

$\ddagger$ Effects with P-values less than 0.01 given **

$\S$ Effects with P-values less than .0001 given * 
661

662

663

664

665

666

\begin{tabular}{|c|c|c|c|c|c|c|c|}
\hline Trait $\dagger$ & Plant Height $\ddagger$ & $\begin{array}{l}\text { Days to } \\
\text { heading }\end{array}$ & $\begin{array}{r}\text { Flag Leaf } \\
\text { Length }\end{array}$ & $\begin{array}{l}\text { Flag Leaf } \\
\text { Width }\end{array}$ & $\begin{array}{l}\text { Panicle } \\
\text { Length }\end{array}$ & $\begin{array}{r}\text { Primary } \\
\text { Branch } \\
\text { Number }\end{array}$ & $\begin{array}{r}\text { Secondary } \\
\text { Branch } \\
\text { Number }\end{array}$ \\
\hline \multirow{2}{*}{$\mathrm{PH}(\mathrm{cm})$} & \multirow{2}{*}{1} & 0.052489 & 0.191061 & 0.167098 & 0.105132 & 0.121957 & 0.165395 \\
\hline & & 0.1925 & $<.0001 *$ & $<.0001 *$ & 0.0089 & 0.0024 & $<.0001 *$ \\
\hline \multirow{2}{*}{ HD (day) } & 0.052489 & \multirow{2}{*}{1} & 0.1798 & 0.018196 & 0.270397 & 0.15137 & 0.241675 \\
\hline & 0.1925 & & $<.0001 *$ & 0.6517 & $<.0001 *$ & 0.0002 & $<.0001 *$ \\
\hline \multirow{2}{*}{ FLL(cm) } & 0.191061 & 0.1798 & \multirow{2}{*}{1} & 0.189338 & 0.574084 & 0.41541 & 0.433789 \\
\hline & $<.0001 *$ & $<.0001^{*}$ & & $<.0001$ & $<.0001 *$ & $<.0001^{*}$ & $<.0001 *$ \\
\hline \multirow{2}{*}{ FLW(cm) } & 0.167098 & 0.018196 & 0.189338 & \multirow{2}{*}{1} & 0.029408 & 0.223711 & 0.111571 \\
\hline & $<.0001^{*}$ & 0.6517 & $<.0001 *$ & & 0.4655 & $<.0001^{*}$ & 0.0055 \\
\hline \multirow{2}{*}{ PL(cm) } & 0.105132 & 0.270397 & 0.574084 & 0.029408 & \multirow{2}{*}{1} & 0.475573 & 0.610198 \\
\hline & 0.0089 & $<.0001^{*}$ & $<.0001$ & 0.4655 & & $<.0001^{*}$ & $<.0001^{*}$ \\
\hline \multirow{2}{*}{ PBN } & 0.121957 & 0.15137 & 0.41541 & 0.223711 & 0.475573 & \multirow{2}{*}{1} & 0.635593 \\
\hline & 0.0024 & 0.0002 & $<.0001 *$ & $<.0001 *$ & $<.0001$ & & $<.0001 *$ \\
\hline SBN & $\begin{array}{r}0.165395 \\
<.0002\end{array}$ & $\begin{array}{r}0.241675 \\
<.0001^{*}\end{array}$ & $\begin{array}{r}0.433789 \\
<.0001^{*}\end{array}$ & $\begin{array}{r}0.111571 \\
0.0055\end{array}$ & $\begin{array}{c}0.610198 \\
<.0001^{*}\end{array}$ & $\begin{array}{r}0.635593 \\
<.0001^{*}\end{array}$ & 1 \\
\hline
\end{tabular}

667

668

669

670

671

672

673

674

675

676

677

678

679

680

681

682

683

684

685

686

687

688

689

Table 5: Correlations between yield traits in F2:3 population

$\dagger$ Traits; PH, plant height; HD, Days of heading; FLL, Flag leaf length; Flag leaf width; PL, Panicle length; PBN, Number of primary branches; SBN, Number of secondary branches $\ddagger$ Effects with $\mathrm{P}$-values less than 0.01 given * 
Table 6: List of QTL detected and parental origin of positive allele for major QTL

692

\begin{tabular}{|c|c|c|c|c|c|c|c|c|c|c|}
\hline Trait & QTL & $\begin{array}{l}\text { Positive } \\
\text { Parental } \\
\text { Allele }\end{array}$ & Location & Left Marker & Right Marker & BP Position & LOD & $\operatorname{PVE}(\%)$ & Add & Dom \\
\hline \multirow[t]{4}{*}{ FLL } & $\begin{array}{l}q F L L 2- \\
1\end{array}$ & & ST & $\mathrm{c} 2 \mathrm{p} 19270352$ & id2007542 & $\begin{array}{l}19,270,353- \\
19,294,608\end{array}$ & 2.70 & 5.81 & -0.71 & -0.80 \\
\hline & $\begin{array}{l}q F L L 2- \\
2\end{array}$ & & ST & SNP-2.28645110. & 2369745 & $\begin{array}{l}28,650,980- \\
31,203,132\end{array}$ & 2.57 & 5.74 & 0.34 & 1.18 \\
\hline & $q F L L 8$ & Lemont & ST & SNP-8.26142013. & 9030959 & $\begin{array}{l}26,144,728- \\
27,300,242\end{array}$ & 3.13 & 8.03 & -1.11 & 0.51 \\
\hline & $q F L W 2$ & Lemont & ST & 2051794 & SNP-2.21778435. & $\begin{array}{l}21,329,057- \\
21,784,305\end{array}$ & 4.04 & 9.21 & -0.05 & -0.03 \\
\hline \multirow[t]{5}{*}{$\mathrm{HD}$} & $q H D 1$ & Lemont & PT & id 1025292 & 1277001 & $\begin{array}{l}39,799,820- \\
40,032,941\end{array}$ & 9.44 & 11.76 & -1.43 & -0.36 \\
\hline & $q H D 2$ & & PT & 2078559 & id2010564 & $\begin{array}{l}22,089,558- \\
24,693,023\end{array}$ & 2.67 & 3.27 & -0.83 & 0.07 \\
\hline & $\begin{array}{l}q H D 7- \\
1\end{array}$ & & PT & 7094244 & rd7002048 & $\begin{array}{l}5,185,191- \\
6,855,960\end{array}$ & 2.54 & 3.55 & -0.31 & 1.06 \\
\hline & $\begin{array}{l}q H D 7- \\
2\end{array}$ & & ST & SNP-7.21232810. & id7004163 & $\begin{array}{l}21,233,804- \\
23,427,756\end{array}$ & 2.73 & 3.45 & -1.88 & -2.63 \\
\hline & qHD8 & Lemont & PT & SNP-8.26142013. & 9030959 & $\begin{array}{l}26,144,728- \\
27,300,242\end{array}$ & 5.51 & 7.23 & -1.10 & -0.32 \\
\hline \multirow[t]{7}{*}{ PL } & $q P L 1$ & LaGrue & ST & SNP-1.37415410. & 1212517 & $\begin{array}{l}37,416,454- \\
37,692,801\end{array}$ & 4.83 & 11.15 & 0.64 & 0.29 \\
\hline & $q P L 2-1$ & LaGrue & ST & id2004711 & SNP-2.11601520. & $\begin{array}{l}9,880,575- \\
11,601,525\end{array}$ & 3.98 & 9.90 & 0.46 & -0.44 \\
\hline & $q P L 2-2$ & LaGrue & PT & SNP-2.11601520. & c2p17996374 & $\begin{array}{l}11,601,525- \\
17,996,375\end{array}$ & 3.10 & 5.09 & 0.46 & -0.06 \\
\hline & $q P L 7-1$ & & PT & rd7002219 & id7004930 & $\begin{array}{l}24,113,175- \\
25,945,760\end{array}$ & 2.96 & 5.10 & -0.48 & -0.14 \\
\hline & $q P L 8-1$ & Lemont & ST & id8006881 & 8980373 & $\begin{array}{l}24,803,160- \\
25,658,584\end{array}$ & 4.42 & 10.12 & -0.55 & -0.20 \\
\hline & $q P L 8-2$ & Lemont & PT & SNP-8.26142013. & 9030959 & $\begin{array}{l}26,144,728- \\
27,300,242\end{array}$ & 5.14 & 8.46 & -0.57 & -0.24 \\
\hline & $q P L 9$ & & ST & rd9002652 & 9563291 & $\begin{array}{l}10,798,265- \\
12,154,616\end{array}$ & 2.82 & 6.21 & -0.26 & 0.46 \\
\hline $\mathrm{PBN}$ & $q P B N 1$ & LaGrue & ST & 1259171 & SNP-1.39395295. & $\begin{array}{l}39,342,234- \\
39,396,339\end{array}$ & 3.36 & 8.14 & 0.71 & 0.41 \\
\hline \multirow[t]{4}{*}{$\mathrm{PH}$} & $\begin{array}{l}q P H 1- \\
1\end{array}$ & & ST & 222467 & SNP-1.7150499. & $\begin{array}{l}7,116,232- \\
7,151,500\end{array}$ & 2.85 & 4.68 & -0.54 & -3.09 \\
\hline & $\begin{array}{l}q P H 1- \\
2\end{array}$ & LaGrue & ST & SNP-1.38422515. & SNP-1.38536811. & $\begin{array}{l}38,423,559- \\
38,537,855\end{array}$ & 17.38 & 32.86 & 6.38 & 2.27 \\
\hline & $\begin{array}{l}q P H 1- \\
3\end{array}$ & LaGrue & PT & 1226391 & rd1000365 & $\begin{array}{l}38,258,929- \\
38,361,942\end{array}$ & 54.39 & 55.11 & 9.90 & -0.01 \\
\hline & $q P H 8$ & LaGrue & PT & SNP-8.26090329. & SNP-8.26142013. & $\begin{array}{l}26,093,044- \\
26,144,728\end{array}$ & 3.65 & 2.38 & 2.01 & 0.29 \\
\hline \multirow[t]{3}{*}{ SBN } & $\begin{array}{l}q S B N 1- \\
1\end{array}$ & LaGrue & ST & SNP-1.38536811. & 1237300 & $\begin{array}{l}38,537,855- \\
38,652,270\end{array}$ & 7.58 & 16.27 & 3.14 & 0.91 \\
\hline & $\begin{array}{l}q S B N 1- \\
2\end{array}$ & & PT & 1226391 & rd1000365 & $\begin{array}{l}38,258,929- \\
38,361,942\end{array}$ & 2.83 & 4.37 & 1.77 & -0.35 \\
\hline & $q S B N 9$ & & PT & rd9002719 & SNP-9.17707021. & $\begin{array}{l}17,416,860- \\
17,708,023\end{array}$ & 2.99 & 4.74 & 1.87 & -0.07 \\
\hline
\end{tabular}

$694 \dagger$ Traits; PH, plant height; HD, Days of heading; FLL, Flag leaf length; Flag leaf width; PL, Panicle length; PBN, 695 Number of primary branches; SBN, Number of secondary branches 
Table 7: List of candidate genes for yield traits

\begin{tabular}{|c|c|c|c|c|}
\hline Gene Id & Gene & Chromosomal Position (bp) & Trait & Description \\
\hline LOC_Os01g66100 & sd-1 & Chr 1: $38382382-38385504$ & $\mathrm{PH}$ & semi dwarf 1 gene \\
\hline LOC_Os01g68120 & DCL3A & Chr1: 39605717 - 39595681 & PBN & $\begin{array}{l}\text { Endoribonuclease } \\
\text { Dicer homolog 3a }\end{array}$ \\
\hline $\begin{array}{l}\text { LOC_Os08g41580, } \\
\text { Os08g0527600 }\end{array}$ & UBP1-5 & Chr 8: 26268141-26263393 & PBN, SBN & $\begin{array}{l}\text { ubiquitin carboxyl- } \\
\text { terminal hydrolase }\end{array}$ \\
\hline $\begin{array}{l}\text { LOC_Os08g41630, } \\
\text { Os08g0528100 }\end{array}$ & UBP1-8 & Chr 8: 26299397 - 26287372 & PBN, SBN & $\begin{array}{l}\text { ubiquitin carboxyl- } \\
\text { terminal hydrolase } \\
\text { family protein }\end{array}$ \\
\hline LOC_Os08g42540 & OTUB1, WTG1 & Chr 8: 26887363 - 26882955 & PFL & $\begin{array}{l}\text { ubiquitin thioesterase } \\
\text { otubain-like }\end{array}$ \\
\hline LOC_Os08g41940 & GW8,OsSPL16 & Chr 8: 26501167 - 26506218 & HD & $\begin{array}{l}\text { SBP-box gene family } \\
\text { member }\end{array}$ \\
\hline LOC_Os08g39890 & $\begin{array}{l}\text { Wealthy farmers } \\
\text { panicle, IPA } \\
1, \text { WFP,OsSPL14 }\end{array}$ & Chr 8: 25278696-25274449 & PFL & SBP-box gene family \\
\hline LOC_Os08g42440 & OsCOL15 & Chr8: 26797181 - 26792824 & HD & $\begin{array}{l}\mathrm{CCT} / \mathrm{B}-\text { box zinc finger } \\
\text { protein }\end{array}$ \\
\hline LOC_Os08g41950 & OsMADS7,S45 & Chr 8: 26507753 - 26512261 & HD & $\begin{array}{l}\text { MADS-box family } \\
\text { gene with MIKCc type- } \\
\text { box }\end{array}$ \\
\hline
\end{tabular}




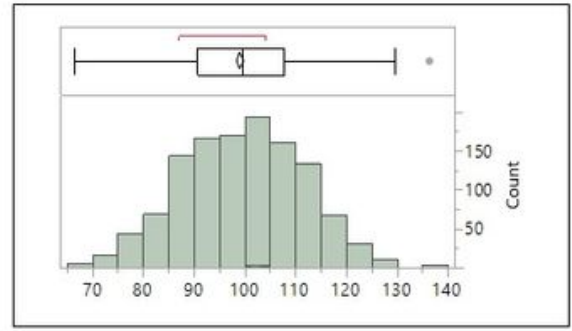

A: Distribution of $\mathrm{PH}$

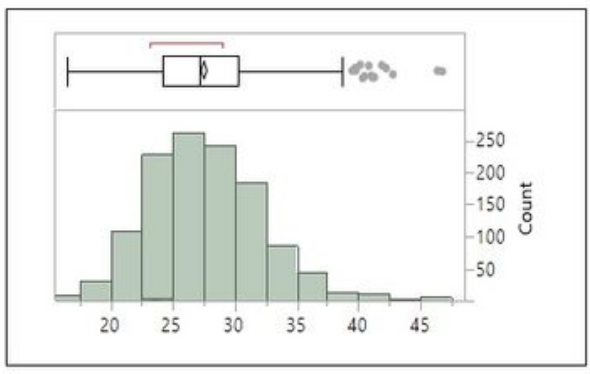

C: Distribution of FLL

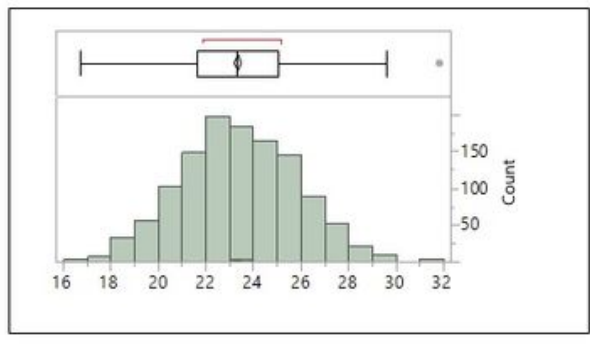

E: Distribution of PL

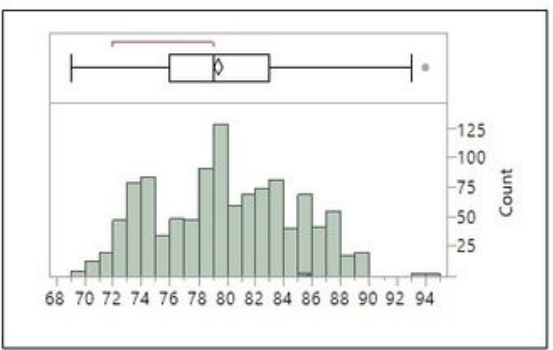

B: Distribution of $\mathrm{HD}$

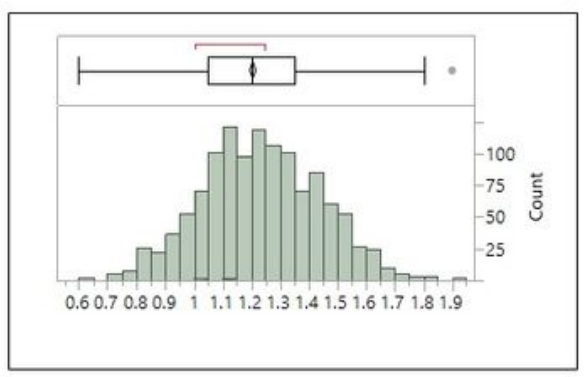

D: Distribution of FLW

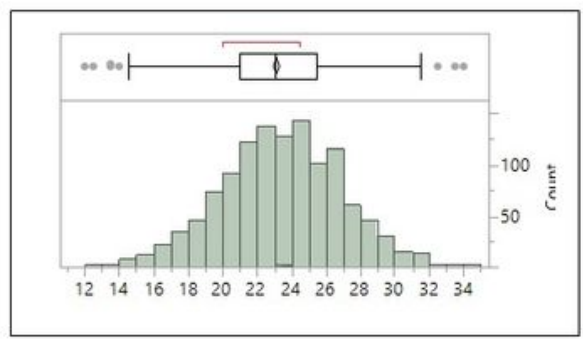

F: Distribution of PBN

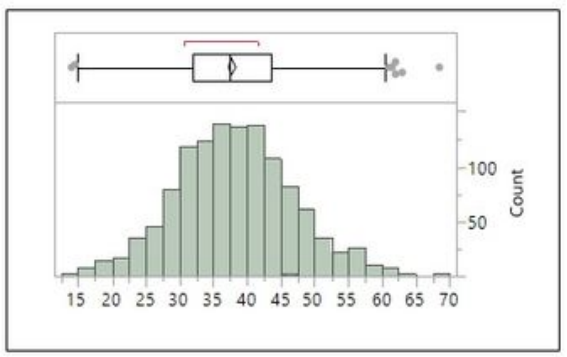

G: Distribution of SBN

\section{Figure 1}

A-G: Distribution of Yield Traits in F2:3 population † Traits; PH, plant height; HD, Days of heading; FLL, Flag leaf length; Flag leaf width; PL, Panicle length; PBN, Number of primary branches; SBN, Number of secondary branches 

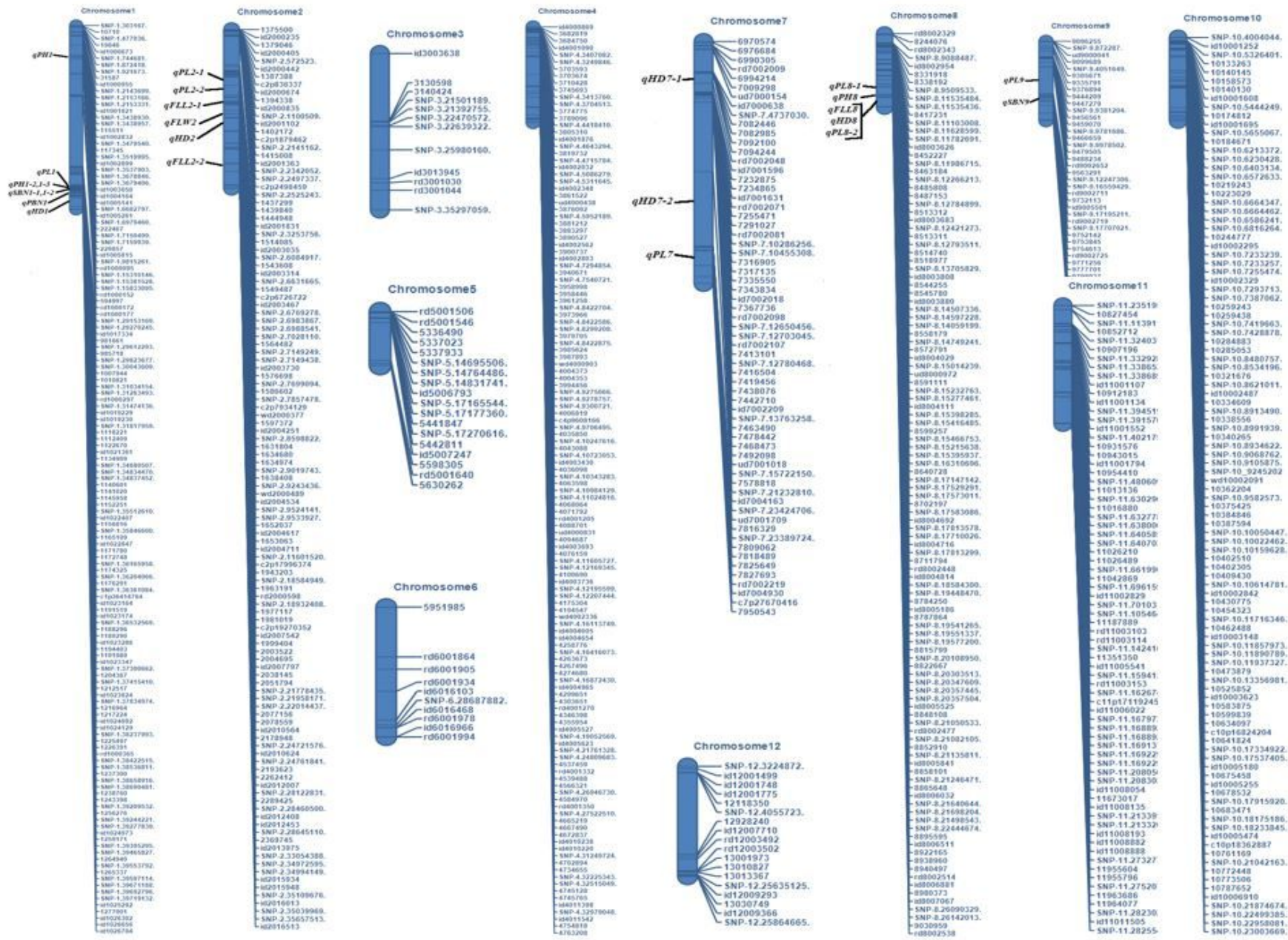

Figure 2

Linkage Map and QTL position in Pine Tree

\section{Image not available with this version}

\section{Figure 3}

One major QTL for number of primary panicle branches qPBN1 was detected on chr. 1 where LaGrue was the positive parental allele (Fig. 3). 